\title{
Effects of Family Empowerment on Increasing Family Support in Patients with Type-2 Diabetes Mellitus
}

\author{
Iskim Luthfa ${ }^{1}$, Iwan Ardian ${ }^{2}$ \\ ${ }^{1,2}$ Nursing Faculty, Sultan Agung Islamic University, Semarang, Indonesia \\ Corresponding Author: Iskim Luthfa (iskimluthfa@ unissula.ac.id)
}

\begin{abstract}
Background: Patients with type-2 Diabetes Mellitus (DM) need support from their families to perform self-care to prevent complications; however, not all families have effective support. Family empowerment is a family-based strategic intervention which can improve family support to those patients.

Purpose: This study aimed to determine the effects of family empowerment on increasing family support in patients with type 2 DM.

Methods: This study used a quasi-experiment with non-equivalent control group design. Forty-six respondents were recruited using a consecutive sampling technique and assigned to the control and intervention groups. Respondents in the intervention group were given family empowerment intervention by visiting their homes four times, for 120 minutes each. In contrast, the control group was given the intervention of standard booklets. The Hensarling Diabetes Family Support Scale (HDFSS) was used to observe the family support on both groups. Data were analyzed by independent t-test.

Results: Results showed that there was a significant difference between the intervention and the control group with $t=7.86$ and $p=0.00$. There were mean differences of 2.29 and 0.28 between the intervention and the control group, respectively.

Conclusion: Family empowerment affected family support in patients with type-2 DM. Based on this study, it is recommended that the health workers advocate and encourage the family in the planning management of patients with diabetes mellitus.
\end{abstract}

Keywords: Family empowerment; family support; type-2 diabetes mellitus

\section{BACKGROUND}

Data on diabetes mellitus (DM) in Indonesia has significantly increased in terms of prevalence and incidence every year. Indonesia is ranked the fourth as the largest country with DM sufferers in the world after the United States, China, and India since 2000. It is estimated that by 2030, Indonesia will remain the fourth with the increase from 8.4 million of DM in 2000 to 21.3 million in 2030 (Wild, Roglic, Green, Sicree, \& King, 2004).

The phenomenon arising these days and worrying is that people experience diabetes mellitus at their youth. The survey conducted by Wild et al. (2004) reported that most of DM with type-2 population in developing countries occurs at the age of 45-64 years while those in developed countries are at the age of more than 64 years. However, based 
on data from the Ministry of Health of the Republic of Indonesia (MOH RI) in 2013, type- 2 diabetes found in the adolescence of 15 years old and above reached about 12 million $(6.9 \%)$, while in the age of teenagers undergoing prediabetes reached 116 million (MOH RI, 2013).

Diabetes Mellitus is a chronic disease which causes people to suffer for their entire lifetime. Due to their youth of being attacked by DM, the patients will experience a lengthy period of illness. To prevent arising complication, DM patients are strongly encouraged to take care of themselves (Sari, Purnawan, Sumeru, \& Taufik, 2018; Suhanda, Afgani, \& Feriandi, 2016). Self-care treatment for people with DM includes treatment of physical activity (exercise), treatment of diet regulation, control of the blood glucose level, medication treatment, and treatment of complication prevention (American Diabetes Association [ADA], 2018)

For patients with DM, obeying a series of self-care routines which will last for a lifetime is a big challenge and not an easy thing to do. Feeling bored and tiresome can occur at any time, which causes people with DM weary in practicing the self-care. Hence, family support is needed to help them to increase their confidence in their ability to keep performing self-care (Tamara, Bayhakki, \& Nauli, 2014).

Family support can be done by optimizing family functions to help patients with type-2 DM to adapt and adhere to the actions of self-care through four dimensions, i.e., empathic dimension (emotional), encouragement dimension (rewards), facilitative dimension (instrumental), and participative dimension (participation) (Hensarling, 2009). Nonetheless, the fact shows that only some families have effective support in dealing with problems of family members with chronic diseases. This is in line with the research conducted by Luthfa (2016) which examined family support for type 2 diabetes mellitus patients. The results reported that out of 56 family respondents, $32.1 \%$ had high support, and $67.9 \%$ had low support.

The efforts to improve family support can be made in some ways. One of which is through family empowerment (Olin et al., 2010). Family empowerment is a nursing intervention used by nurses to assist families in caring for and providing support to family members with chronic illness and is seen as the most important element for treatment success (Graves \& Shelton, 2007). Previous research has proven that family empowerment can improve family support (Olin et al., 2010), as well as the increase of the self-care of the sick (Muhtar, 2013), which will have an impact on improving the quality of life of family members who experience chronic illness (Kashaninia, Payrovee, Soltani, \& Mahdaviani, 2018). Previous research has also explained the positive effects of family empowerment on family support that emphasizes more on optimizing family roles and functions.

Management of DM by involving families is currently being developed. Nurses as health care providers should not only examine the characteristics of respondents starting from knowledge, attitudes and health care skills, but also examine family and cultural characteristics that can affect the assessment of health (Kosegeran, Ratag \& Kumaat, 2017). Nursing intervention is not only given to the sick individuals, but also the 
families who care for them. There is limited evidence of family empowerment to increase family support in patients with DM. Thus, conducting a study on the effects of family empowerment on increasing family support is necessary.

\section{PURPOSE}

The purpose of this study was to determine the effects of family empowerment on increasing family support in patients with type- 2 diabetes mellitus.

\section{METHODS}

\section{Research design}

This study used a quasi-experiment with non-equivalent control group research design.

\section{Samples and setting}

The samples were taken by using Jacob Cohen's formula (Polit \& Beck, 2001), with a significant level (SL) of $95 \%(\alpha=0.05)$, power of test of 0.8 and effect size of 0.86 . The samples were 56 and were assigned to two groups, i.e., the intervention group consisting of 28 respondents given family empowerment intervention by visiting their homes four times for 120 minutes each, and the control group consisting of 28 respondents given the intervention of standard booklets. The inclusion criteria included the families who: (1) have cared for and lived in one house with type 2 DM patients, (2) aged of 20-65 years, (3) hold at least elementary education, and (4) had health insurance. The exclusion criteria were families having members with chronic diseases other than DM, such as stroke, HIV, TB, and others.

\section{Research instrument and data collection}

The research instruments used were learning event units (LEU) and booklets for DM care guidelines. The LEU consists of 4 stages adopted from the family empowerment intervention with chronic diseases (Wise, 2005). The instrument used to find out family support was the questionnaire of Hensarling Diabetes Family Support Scale (HDFSS). The HDFSS consists of 29 question items that cover four dimensions of support, namely, emotional support/empathy, support for appreciation, instrumental support, and information support (Hensarling, 2009).

The implementation of the family empowerment strategy adopted the nursing process approach through four stages of home visits with a pause of every one week visit (each home visit was allocated for 120 minutes). The interventions were carried out by referring to the LEU protocol that had been prepared. The implementation of material intervention refers to the standard material in the booklet (guidebook) about DM and its treatment.

In the first phase (professional dominated phase), the researchers conducted DTR (developing trust relationships) and initial data collection by organizing pre-testing using the Hensarling Diabetes Family Support Scale (HDFSS) instrument in the experimental and control groups. In the second phase (participatory phase), home visits were carried out in the intervention group. The intervention material provided referred to the standard material contained in the booklet relating to the concept of DM disease and ways to prevent complications. The intervention was carried out by involving the 
whole family members (caregivers) using the booklet and audiovisual media (animated images). The methods used were lectures, discussions, guidance or counseling, and demonstrations. In the third phase (challenging phase), home visits were carried out in the intervention group. The intervention at this stage was carried out to strengthen the role and function of the family in providing support to family members who have type 2 diabetes. The material presented at the third visit referred to the standard material in the booklet, which is related to how to treat DM at home and the form of family support that can be given. At this third stage, the process of transferring roles occurred from nurses to families to provide support to family members who have type 2 diabetes. Finally, the fourth phase (Collaborative phase), the last intervention was conducted by evaluating the two groups. Researchers administered a post-test using the Hensarling Diabetes Family Support Scale (HDFSS) instrument to determine the extent to which families were able to provide support after the intervention.

The evaluation of family support improvement was carried out one week after the intervention in the third phase. One-week time was considered effective because the evaluation only measured the family's ability to provide support at this time, so it was possible that this result is still temporary. Meanwhile, to measure the ability of families to recognize health problems in the future independently and not to experience dependence on health services, repeated interventions (booster) can be carried out every three months, and evaluations can be done a year later. Evaluation in a one-year period is considered to be able to improve the results of permanent family support. After being given the family empowerment intervention, the family gave an appreciation that the educational program with home visits like this was considered effective because it involved families that one whole family could understand DM.

\section{Data analysis}

Univariate analysis was performed using the RASCH measurement model. The RASCH model was used due to its ability to convert ordinal data into intervals by transforming logarithms to odd ratio functions. Thus, the data obtained were in the form of equal and interval, displayed in the form of logit value (logarithm odds digit) measure. This logit measure value was then used by the researcher for the bivariate analysis test by using the independent t-test.

\section{Ethical consideration}

This study was approved by the health research ethics committee at the Nursing Faculty, Sultan Agung Islamic University (Unissula) Semarang with the number 207/A.1/FIKSA/VII/2018.

\section{RESULTS}

\section{Demographic characteristics of respondents}

The majority of respondents in both groups ranged from 51 to 60 years old. The sex of the respondents in both groups was mostly female. Most of the respondents both groups graduated from an elementary school. The majority of respondents in both groups suffered from type 2 diabetes mellitus for $<1$ year. The variables of age, gender, education, and length of DM had a p-value <0.05, which indicates that the four variables in the intervention group and the control group had the same characteristics. 
Table 1. Characteristics of respondents in the study

\begin{tabular}{|c|c|c|c|c|c|}
\hline \multirow[t]{2}{*}{ Variable } & \multicolumn{2}{|c|}{ Intervention $(\mathrm{n}=28)$} & \multicolumn{2}{|c|}{ Control $(n=28)$} & \multirow[t]{2}{*}{$p$} \\
\hline & $f$ & $\%$ & $f$ & $\%$ & \\
\hline \multicolumn{6}{|l|}{ Age } \\
\hline $30-40$ & - & - & - & - & \multirow{5}{*}{0.00} \\
\hline $41-50$ & 7 & 25.0 & 5 & 17.9 & \\
\hline $51-60$ & 19 & 67.9 & 20 & 71.4 & \\
\hline $61-70$ & 2 & 7.1 & 3 & 10.7 & \\
\hline$>71$ & - & - & - & - & \\
\hline \multicolumn{6}{|l|}{ Sex } \\
\hline Male & 11 & 39.3 & 10 & 35.7 & \multirow[t]{2}{*}{0.00} \\
\hline Female & 17 & 60.7 & 18 & 64.3 & \\
\hline \multicolumn{6}{|l|}{ Education } \\
\hline Elementary school & 11 & 39.3 & 13 & 46.4 & \multirow{4}{*}{0.00} \\
\hline Junior high school & 5 & 17.9 & 3 & 10.7 & \\
\hline Senior high school & 10 & 35.7 & 10 & 35.7 & \\
\hline University & 2 & 7.1 & 2 & 7.1 & \\
\hline \multicolumn{6}{|l|}{ The length of the illness } \\
\hline$<1$ years & 14 & 50.0 & 16 & 57.1 & \multirow{4}{*}{0.00} \\
\hline $1-5$ years & 12 & 42.9 & 10 & 35.7 & \\
\hline $6-10$ years & 1 & 3.6 & 1 & 3.6 & \\
\hline$>10$ years & 1 & 3.6 & 1 & 3.6 & \\
\hline
\end{tabular}

\section{Demographic characteristics of family (caregivers)}

Most of the respondent family types in the two groups were nuclear family. The caring family members (primary caregivers) in both groups were mostly husbands. The education of the caregivers in both groups was mostly high school level. The economic status based on regional minimum wages (RMW) per month in the intervention group was in balance where as many as 14 respondents $(50.0 \%)$ received wages below the RMW and as many as 14 respondents $(50.0 \%)$ received wages above the RMW. In the control group, respondents who received wages below the RMW were 16 (57.1\%). The variables of family type, caregiver, education and economic status in Table 2 have a pvalue $<0.05$, which means that the four variables in the intervention group and the control group had the same characteristics.

Table 2. Characteristics of the family (caregivers)

\begin{tabular}{lrrrrl}
\hline Variable & \multicolumn{2}{c}{ Intervention $(\mathrm{n}=28)$} & \multicolumn{2}{c}{ Control $(\mathrm{n}=28)$} & \multirow{2}{*}{$p$} \\
\cline { 2 - 5 } & \multicolumn{1}{c}{$\%$} & $\%$ & \multicolumn{1}{c}{$f$} & $\%$ & \\
\hline Family type & & & & & \\
$\quad$ Nuclear Family & 23 & 82.1 & 25 & 89.3 & 0.00 \\
$\quad$ Extended Family & 5 & 17.9 & 3 & 10.7 & 0.00 \\
Caregiver & & & & & \\
$\quad$ Husband & 12 & 42.9 & 12 & 42.9 & \\
$\quad$ Wife & 11 & 39.3 & 10 & 35.7 & \\
$\quad$ Child & 5 & 17.9 & 6 & 21.4 & \\
Education & & & & & \\
$\quad$ Elementary school & 8 & 28.6 & 9 & 32.1 & \\
\hline
\end{tabular}




\begin{tabular}{|c|c|c|c|c|c|}
\hline \multirow[t]{2}{*}{ Variable } & \multicolumn{2}{|c|}{ Intervention $(\mathrm{n}=28)$} & \multicolumn{2}{|c|}{ Control $(n=28)$} & \multirow[t]{2}{*}{$p$} \\
\hline & $f$ & $\%$ & $f$ & $\%$ & \\
\hline Junior high school & 5 & 17.9 & 5 & 17.9 & \\
\hline Senior high school & 14 & 50.0 & 13 & 46.4 & \\
\hline University & 1 & 3,6 & 1 & 3.6 & \\
\hline \multicolumn{6}{|l|}{ Economy } \\
\hline$<$ RMW & 14 & 50.0 & 16 & 57.1 & 0.00 \\
\hline$>$ RMW & 14 & 50.0 & 12 & 42.9 & \\
\hline
\end{tabular}

\section{Differences of the family support after the intervention in both groups}

The result of the paired t-test in the intervention group obtained a value of 9.31 for the $t$ count and $p=0.00$ was smaller than the value of $\alpha(0.05)$ (Table 3$)$, meaning that there were differences in the family support level before and after given family empowerment intervention strategies. Based on the mean value before and after the intervention, it was found that there was a significant difference in the mean value of 2.29. This explained that giving a family empowerment intervention strategy significantly improved family support in the intervention group.

The results of the paired t-test in the control group obtained $t=3.95$ and $p=0.00$, which was smaller than the value of $\alpha(0.05)$, meaning that there was a difference in family support level before and after the intervention. Based on the mean value before and after the intervention, the difference was very small as equal to 0.278. This described that although there was an increase in the family support, yet it was not statistically significant in the control group.

Table 3. Mean differences of the family support after the intervention in both groups

\begin{tabular}{llllll}
\hline \multirow{2}{*}{ roup } & \multicolumn{2}{c}{ Logit Person Measure } & Mean \\
& $\begin{array}{l}\text { Pre } \\
\text { Mean }(S D)\end{array}$ & $\begin{array}{l}\text { Post } \\
\text { Mean }(S D)\end{array}$ & $t$ & $p$ \\
& Difference & & \\
\hline Intervention & $0.07(1.40)$ & $2.35(1.86)$ & 2.29 & 9.31 & 0.00 \\
\hline Control & $-1.22(1.31)$ & $-0.94(1.44)$ & 0.278 & 3.95 & 0.00 \\
\hline
\end{tabular}

\section{The difference in family support after the intervention in both groups}

The results of the independent t-test on the difference in logit person measure of the family support variable between the intervention group and the control group. The data shows that the t-test value was 7.86, and the p-value was 0.00 , smaller than the value of $\alpha(0.05)$, meaning that there was a significant influence of giving family empowerment intervention strategies to increase the family support.

Table 4. The difference in family support after the intervention in both groups

\begin{tabular}{|c|c|c|c|c|c|c|}
\hline \multirow[t]{2}{*}{$\begin{array}{l}\text { Family } \\
\text { Support }\end{array}$} & \multicolumn{2}{|c|}{$\begin{array}{l}\text { Logit Person Measure } \\
\text { Intervention Groups }\end{array}$} & \multicolumn{2}{|c|}{$\begin{array}{l}\text { Logit Person Measure } \\
\text { Control Groups }\end{array}$} & \multirow[t]{2}{*}{$t$} & \multirow[t]{2}{*}{$p$} \\
\hline & Mean & $S D$ & Mean & $S D$ & & \\
\hline $\begin{array}{l}\text { Differences } \\
\text { measure }\end{array}$ & 2.29 & 1.30 & 0.28 & 0.37 & 7.86 & 0.00 \\
\hline
\end{tabular}




\section{DISCUSSION}

This study aimed to determine the effects of family empowerment on increasing family support in patients with type $2 \mathrm{DM}$. The results of the study showed that the nursing intervention strategy through family empowerment could increase the family support for patients with type 2 diabetes mellitus. Family empowerment is a solution to overcome family health problems independently (Graves \& Shelton, 2007). However, the ability to communicate and understand health problems extensively may become a challenge for nurses in carrying out family empowerment. Through family empowerment, nurses try to improve communication skills, problem-solving skills, conflict resolution skills (individual and family handling), and self-care management skills (Shields, Finley, Chawla, \& Meadors, 2012).

The concept of family empowerment has three main components. Family empowerment is a dynamic process, involves the role of the family, and requires an intervention framework for the implementation of family empowerment (Olin et al., 2010). Referring to the concept of the component, family empowerment has a broad purpose dimension. Family empowerment helps the families through the process of changes that will be carried out, builds resilience and adaptability of the family, explores and increases the potential of the family, the role and function of the family health, the mediation of family-centered care relationships, and family competencies of managing health problems, as well as fosters and assists families to the stage of independence (Graves \& Shelton, 2007; Olin et al., 2010; Whitley, Kelley, \& Campos, 2011; Wise, 2005).

Family empowerment involves all components of the family, including parents and children. Nurses try to explore the potential of the family and try to develop it. Interactive education methods are the right model in the family empowerment (Graves $\&$ Shelton, 2007). Family empowerment is a nurse intervention strategy that is seen as an important element in health promotion programs, in which it provides self-care behavior information (Malini, Yeni, \& Saputri, 2018), and increases family trust in caring to improve the quality of life (Baffour \& Chonody, 2012; Maryam, Resnayati, Riasmini, \& Sari, 2018). The empowerment of families with family members who experience chronic diseases is given by providing accurate and complete information about the condition of the disease and management of its care, prioritizing a sense of empathy as well as showing genuine concern, and this can improve family competency in caring for the sick family members. Anticipating the prognosis of diabetes mellitus is difficult, but some previous studies have suggested that low self-care is a major factor. Therefore, family empowerment on how to self-care for people with DM is a very important thing to be given. Family empowerment in patients with type 2 DM emphasizes two important aspects, namely management of care and effective interaction between families and nurses. Empowerment-based interventions regard families as partners. Family empowerment in patients with type 2 diabetes mellitus aims to control DM disease by increasing knowledge, skills, competence, and family resources (Nachshen, 2005).

Previous research has shown that family support is an important factor in compliance with management of chronic diseases, and also as an indicator of the positive impact on self-care of diabetic patients (Mayberry \& Osborn, 2012). However, in reality, not all 
families have effective support in dealing with problems of family members with chronic diseases because of low knowledge (Kovacs et al., 2013). Family support is a process of providing assistance provided by the family to other family members who have health problems to maintain and improve their health status. Family is the most important source of support. The supports that the families provide to patients with type 2 diabetes mellitus include four dimensions, i.e., emotional support/empathy, appreciation support, instrumental support, and information support (Hensarling, 2009). Emotional support is the most important form of support and is the basis of the other three forms of support. Emotional support is included in the affective function of the family. Support provided by the family can be in the form of trust, empathy, understanding, attention, security, love and affection, and encouragement (Friedman, Bowden, \& Jones, 2010). Giving emotional support will encourage people with type 2 diabetes to be able to control emotions, and be able to reduce despair, reduce feelings of inferiority (Nugroho, 2000). The appreciation support refers to the assessment of the family in the form of giving feedback (Bomar, 2004) that can be in the form of praise, guidance, and attention. The appreciation support may improve psychosocial status, enthusiasm, motivation, and increase the self-esteem of patients with DM. The instrumental support is real and direct assistance provided by the family in the form of labor assistance, facilities, funds, including providing free time to serve and listen to complaints of sick family feelings. Instrumental support is included in the economic function and family health care function. The economic function refers to the fulfillment of financial needs of family members to maintain their health, and the family health care includes providing free time for discussion, doing care at home, providing adequate shelter, providing food and helping to help with health care facilities. As family is the most important source of information, it is easier for people with diabetes mellitus to receive information and be motivated to maintain their health, and this information is supported by the family which can be in the form of advice and information about food diet, physical activity, conditions or symptoms of DM complications, and how to treat it (Friedman et al., 2010).

Family support is influenced by several factors (Friedman et al., 2010). In this study, most of the family is the first type of family (nuclear family). Qualitatively, people with diabetes mellitus who come from nuclear families will receive more support than patients who come from extended families. However, quantitatively, people with diabetes mellitus have the possibility to get more support from extended families who live together. Furthermore, the majority of caregivers in this study is the husband - the head of the family, who is seen as someone who holds power and makes decisions. The majority of caregivers also hold the third level of education so that they can be the family support providers. Education is associated with the ability to receive information. The higher the education of the family support providers, the better they will be in receiving information that will increase the support for people with DM. Furthermore, support is also influenced by the socio-economic condition of the family that is associated with the level of income or employment. Middle to upper socioeconomic families tend to have higher levels of support, affection, and involvement than parents or families with lower socio-economic levels (Friedman et al., 2010). 
The results of this study showed that the family empowerment strategy influenced family support in patients with type 2 diabetes. Although several factors outside the intervention may have an influence on increasing family support, yet the researchers have tried to minimize the confounding variable through the use of matching techniques to include respondents into the intervention group and the control group based on the characteristics of the respondent and family. Furthermore, the selection of samples has been carried out through a selection based on the inclusion and exclusion criteria which the researchers set. This strategy is considerably right to be used to help families dealing with chronic diseases. This strategy emphasizes that the family as a system has mutual influences where imbalances within the family if come out, will affect all family systems.

\section{CONCLUSION}

The results of this study indicated that family empowerment had a positive effect on increasing family support in patients with type- 2 diabetes mellitus. These results may contribute to the improvement of intervention strategies used by community nurses to develop a family-based chronic disease management program. Further research directed at achieving long-term goals of family independence may be conducted by recognizing the possible future health problems so that the families do not experience dependence on health services. Also, following up family empowerment intervention strategies a year later may be necessary.

\section{ACKNOWLEDGMENT}

The researchers would like to thank Sultan Agung Islamic University (Unissula) Semarang for funding this study. We also thank the participants who participated in this study.

\section{CONFLICT OF INTEREST}

The authors declare no conflict of interest.

\section{REFERENCES}

American Diabetes Association (ADA). (2018). Standards of medical care in diabetes 2018. Diabetes Care, 41(1), s55-s64.

Baffour, T., \& Chonody, J. (2012). Do empowerment strategies facilitate knowledge and behavioral change? The impact of family health advocacy on health outcomes. Social Work in Public Health, 27(5), 507-519. Doi: 10.1080/19371918.2010.494991

Bomar, P.J. (2004). Promoting health in families: Applying family research and theory to nursing practice. Saunders: Lippincott

Friedman, M. M., Bowden, O., \& Jones, M. (2010). Buku ajar keperawatan keluarga: Riset, teori dan praktik [Family nursing textbooks: Research, theory and practice]. (5th ed.) (Achir Yani S. Hamid, Trans). Jakarta: EGC.

Graves, K., \& Shelton, T. (2007). Family empowerment as a mediator between familycentered systems of care and changes in child functioning: Identifying an important mechanism of change. Journal of Child \& Family Studies, 16(4), 556566. Doi: 10.1007/s10826-006-9106-1 
Hensarling, J. (2009). Development and psychometric testing of Hensarling's diabetes family support scale (Doctoral Dissertation). Graduate School of Texas Women's University.

Kashaninia, Z., Payrovee, Z., Soltani, R., \& Mahdaviani, S. (2018). Effect of family empowerment on asthma control in school-age children. Journal of Respiratory Disease, Thoracic Surgery, Intensive Care and Tuberculosis, 17(1), 47-52.

Kosegeran, B., Ratag, G. A., \& Kumaat, L. (2017). Gambaran pengetahuan dan sikap penderita diabetes mellitus (DM) di Wilayah Kerja Puskesmas Tinoor [The description of knowledge and attitudes of people with diabetes mellitus (DM) in the Tinoor health center working area]. Jurnal Keperawatan, 5(2), 1-6.

Kovacs, B. K., Nicolucci, A., Holt, R., Willaing, I., Hermans, N., Kalra, S., ... \& Peyrot, M. (2013). Diabetes attitudes, wishes and needs second study (DAWN2 ${ }^{\mathrm{TM}}$ ): Cross-national benchmarking indicators for family members living with people with diabetes. Diabetic Medicine, 30(7), 778-788. Doi: $10.1111 /$ dme. 12239

Luthfa, I. (2016). Family support pada penderita diabetes mellitus tipe 2 di Puskesmas Bangetayu Semarang, analisis RASCH model [Family support for patients with type 2 diabetes mellitus at Bangetayu Semarang health center, a RASCH analysis model]. Jurnal Keperawatan dan Pemikiran Ilmiah Nurscope, 2(2), 1-12.

Malini, H., Yeni, F., \& Saputri, D. E. (2018). The effect of InGDEP on type 2 diabetes patients' knowledge and self-care. Jurnal Keperawatan Padjadjaran, 6(3), 235242. doi: $10.24198 / \mathrm{jkp} . v 6 i 3.696$

Maryam, R. S., Resnayati, Y., Riasmini, N. M., \& Sari, C. W. (2018). Effect of family support intervention towards quality of life with elderly's hypertension in community. Jurnal Keperawatan Padjadjaran, 6(3), 280-288. doi: 10.24198/jkp.v6i3.696

Mayberry, L.S. \& Osborn, C.Y. (2012). Family support, medication adherence, and glycemic control among adults with type 2 diabetes. Journal of Diabetes Care, 35(6), 1239-1245. doi: 10.2337/dc11-2103

Ministry of Health Republic Indonesia (MOH RI). (2013). Riset kesehatan dasar [Basic health research]. Jakarta: Badan Penelitian dan Pengembangan Kesehatan Kementrian Kesehatan RI.

Muhtar. (2013). Pemberdayaan keluarga dalam peningkatan self-efficacy dan self-care activity keluarga dan penderita TB paru [Family empowerment in increasing selfefficacy and self-care activities in families and people with pulmonary TB]. Jurnal Ners, 8(2), 229-239. doi: 10.20473/jn.v8i2.3826

Nachshen, J. (2005). Empowerment and families: building bridges between parents and professionals, theory and research. Journal on Developmental Disabilities, 11(1), 67-75. Doi: 10.1.1.575.9567

Nugroho, W. (2000). Keperawatan gerontik [Gerontological nursing]. Jakarta: Gramedia

Olin, S., Hoagwood, K., Rodriquez, J., Ramos, B., Burton, G., Penn, M., ... Jensen, P. (2010). The application of behavior change theory to family-based services: Improving parent empowerment in children's mental health. Journal of Child \& Family Studies, 19(4), 462-470. doi: 10.1007/s 10826-009-9317-3

Polit, D., \& Beck, C. (2001). Nursing research: Principles and methods (seventh ed.). Philadelphia: Lippincott Williams \& Wilkins. 
Sari, Y., Purnawan, I., Sumeru, A., \& Taufik, A. (2018). Quality of life and associated factors in Indonesian diabetic patients with foot ulcers. Nurse Media Journal of Nursing, 8(1), 13-24. doi: 10.14710/nmjn.v8i1.16815

Shields, C., Finley, M., Chawla, N., \& Meadors, W. (2012). Couple and family interventions in health problems. Journal of Marital and Family Therapy, 38(1), 265-280. doi: 10.1111/j.1752-0606.2011.00269.x

Suhanda, Y., Afgani, A., \& Feriandi, Y. (2016). Gambaran tingkat self-care pada pasien rawat jalan diabetes melitus tipe 2 di RSUD Al-Ihsan Provinsi Jawa Barat [The overview of self-care level in type 2 diabetes mellitus outpatients in Al-Ihsan General Hospital, West Java Province]. Prosiding Pendidikan Dokter, 2(2), 630637). Retrieved from http://karyailmiah.unisba.ac.id/index.php/dokter/index

Tamara, E., Bayhakki, \& Nauli, F. (2014). Hubungan antara dukungan keluarga dan kualitas hidup pasien diabetes mellitus tipe II di RSUD Arifin Achmad Provinsi Riau [Relationship between family support and quality of life of patients with type II diabetes mellitus at Arifin Achmad Hospital in Riau Province]. Jurnal Online Mahasiswa PSIK UNRI, 1(2), 1-7.

Whitley, D., Kelley, S., \& Campos, P. (2011). Perceptions of family empowerment in African American Custodial grandmother raising. Families in Society, 92(4), 110119. Doi: 10.1606/1044-3894.4148

Wild, S., Roglic, G., Green, A., Sicree, R., \& King, H. (2004). Global prevalence of diabetes: Estimates for the year 2000 and projections for 2030. Journal of Diabetes Care, 27(5), 1047-1053.

Wise, J. (2005). Empowerment practice with families in distress. New York: Columbia University Press. 